\title{
EL ARTÍCULO 24 DE LA CONSTITUCIÓN ESPAÑOLA Y LA PRUEBA DE ADN EN EL PROCESO PENAL
}

\author{
Article 24 of the Spanish constitution \\ and the DNA evidence in criminal proceedings
}

\author{
VICTORIA ÁLVAREZ BUJÁN \\ Universidad de Vigo \\ victoriaalvarezbujan@gmail.com \\ Cómo citar/Citation \\ Álvarez Buján, V. (2018) \\ El artículo 24 de la Constitución Española y la prueba de ADN en el proceso penal. \\ Revista Española de Derecho Constitucional, 114, 131-161. \\ doi: https://doi.org/10.18042/cepc/redc114.05
}

\section{Resumen}

El presente trabajo pretende ofrecer un análisis de las principales singularidades que entraña la práctica de pruebas de ADN en el ámbito del proceso penal y la inscripción de identificadores genéticos en la base de datos policial, haciendo especial hincapié en las garantías previstas en la Constitución y en la legislación procesal de aplicación por las que se deben regir tales actuaciones. En este contexto concederemos especial relevancia al derecho de defensa y a la presunción de inocencia, que guardan una estrecha relación con la forma en la que los resultados de un análisis genético han de adquirir eficacia probatoria y con el modo en el cual deben ser interpretados para que se pueda concluir que la inferencia probatoria llevada a efecto y, por ende, la fundamentación de la sentencia han sido correctas y acordes con la consecución de la tutela judicial efectiva.

\section{Palabras clave}

Prueba de ADN, proceso penal; valoración probatoria; presunción de inocencia; derecho de defensa; tutela judicial efectiva. 


\section{Abstract}

This study aims to offer an analysis of the main singularities involved in the practice of DNA evidence in the field of criminal proceedings and the registration of genetic identifiers in the police database, with special emphasis on the guarantees established for the Constitution and the procedural legislation of application by which such actions must be directed. In this context, we will concede special importance to the right of defense and the presumption of innocence that are closely related to the manner in which the results of a genetic analysis must acquire evidentiary value and the way in which they must be interpreted, in order to be able to conclude that the probationary inference taken into effect and, therefore, the basis of the sentence have been correct and appropriate to achieve the effective judicial protection.

\section{Keywords}

DNA evidence; criminal proceedings; probationary assessment; presumption of innocence; right of defense; effective judicial protection. 


\section{SUMARIO}

I. NOTAS INTRODUCTORIAS. II. EL MARCO NORMATIVO GENERAL EXISTENTE ANTES Y DESPUÉS DE LA REFORMA OPERADA POR LA LEY ORGÁNICA 13/2015, DE 5 DE OCTUBRE: 1. Problemática ligada a la existencia de lagunas y parquedad normativa. 2. La cuestionable actuación del Tribunal Supremo para justificar la «validez» de la obtención de muestras biológicas «atribuidas» o «abandonadas». 3. La necesidad de implementar y utilizar, con fines de investigación criminal, una base de datos unificada comprensiva de identificadores de ADN y las deficiencias que alberga la Ley Orgánica 10/2007, de 8 de octubre. 4. Aspectos esenciales de las reformas legales operadas en el año 2015. III. LA ASISTENCIA LETRADA INTEGRAL COMO GARANTÍA INEXCUSABLE. IV. LA OTRA CARA DE LA MONEDA: PRUEBAS DE ADN PRACTICADAS A INSTANCIA DE LA DEFENSA. V. LOS RESULTADOS DE UN ANÁLISIS DE ADN: LA SIMBIOSIS ENTRE LA CORRECTA VALORACIÓN PROBATORIA Y LA PRESERVACIÓN DEL DERECHO DE DEFENSA Y LA PRESUNCIÓN DE INOCENCIA. VI. CONCLUSIONES. VII. BIBLIOGRAFÍA.

\section{NOTAS INTRODUCTORIAS}

Resulta indiscutible que en los últimos años la prueba de ADN se ha convertido en un elemento clave en el marco de un gran número de investigaciones y procesos penales. Ello responde al hecho de que, en ocasiones, ante la ausencia de otros vestigios, pruebas o indicios, el análisis de contraste de perfiles genéticos (dubitados ${ }^{1}$ e indubitados ${ }^{2}$ ) es el único medio que posibilita la determinación de la — presunta- autoría de los hechos punibles.

En este orden de composición, al margen del examen de la regulación -insuficiente y falta de sistematicidad - que recoge la Ley de Enjuiciamento Criminal (LECrim) en sus arts. 326.3, 636. 2 y 520. 6 c), así como de ciertas deficiencias que presenta la Ley Orgánica 10/2007, de 8 de octubre, reguladora de la base de datos policial sobre identificadores obtenidos a partir del ADN y que plantean notables problemas en la praxis judicial, proporcionaremos un enfoque de cariz constitucional a nuestro trabajo. Así, en primer término, partiremos del postulado del primer apartado del art. 24 de la Constitución Española, que reconoce el derecho de todas las personas «a obtener la tutela efectiva

\footnotetext{
1 Los hallados en la escena de los hechos o en el cuerpo de la víctima.

2 Los recabados directamente de la persona sospechosa/investigada mediante la realización de una medida de intervención corporal leve, como un frotis bucal.
} 
de los jueces y tribunales en el ejercicio de sus derechos e intereses legítimos, sin que, en ningún caso, pueda producirse indefensión», lo que, entre otras cuestiones, en el marco de un proceso - penal - implica que para que una prueba pueda ser tomada en consideración por el órgano judicial debe gozar de licitud $^{3}$, pues solamente así será apta para enervar la presunción de inocencia.

Sin lugar a dudas, el proceso penal es, a la postre, el símil de un juego en el que se puede utilizar una amplia variedad de elementos (léase la práctica de pruebas de $\mathrm{ADN}$ ), pero respetando siempre, de forma ineludible, determinadas reglas que se traducen en las garantías constitucionales y procesales. En consecuencia, toda vez que el citado ejemplo $-\mathrm{y}$ eje en relación al cual pivota nuestro estudio - constituye una diligencia limitadora de derechos fundamentales ${ }^{4}$, debe sujetarse al estricto cumplimiento de los principios de legalidad y proporcionalidad. Este último se encuentra integrado por distintos elementos: el subprincipio de necesidad, entendido como indispensabilidad de la medida $a^{5}$ el subprincipio de idoneidad, lo que implica que la concreta actuación ha de ser adecuada al propósito perseguido; el subprincipio de proporcionalidad en sentido estricto, que significa que de la medida en cuestión deberán derivarse más beneficios para el interés general que perjuicios en los derechos de la persona afectada por su práctica y, de modo complementario a lo anterior, la necesidad de que con carácter previo exista una finalidad legítima para llevar a cabo la concreta restricción de derechos fundamentales, en los términos propugnados por el Tribunal Constitucional (STC 55/1996, de 28 de marzo) ${ }^{6}$. A tales subprincipios o exigencias deben

3 En definitiva y dicho de otro modo, para desvirtuar esta presunción es preciso que los medios de prueba utilizados en el juicio oral hayan sido válida y lícitamente obtenidos. Véanse entre otras muchas, las SSTC 64/1986, de 21 de mayo, y 82/1988, de 28 de abril.

4 Que no son absolutos, sino que pueden ceder en aras de proteger otros bienes o intereses superiores del ordenamiento jurídico. El Tribunal Constitucional ha venido remarcando el carácter limitable de los derechos fundamentales, desde hace ya muchos años, en numerosas de sus resoluciones, entre las que podemos señalar: SSTC 2/1982, de 29 de enero; 91/1983, de 7 de noviembre; 120/1983, de 15 de diciembre; 57/1994, de 28 de febrero; 143/1994, de 9 de mayo; 98/2000, de 10 de abril; 186/2000, de 10 de julio, y 156/2001, de 2 de julio (la más reciente) y 115/2013, de 9 de mayo. Véanse igualmente la STS 169/2015, de 13 de marzo, como referente en lo que respecta a la práctica de medidas de intervención corporal y pruebas de ADN, así como las SSTC 7/1994, de 17 de enero, y 207/1996, de 16 de diciembre.

5 No habiendo otra medida menos lesiva o de menor entidad para conseguir el mismo objetivo (Bernal Pulido, 2007: 740).

6 El fin legítimo es un elemento que se incluye dentro del principio de justificación teleológica, el cual es examinado con detalle por González-Cuéllar Serrano (1990: 101-105). 
añadirse la concurrencia de gravedad delictiva en los hechos objeto de investigación ${ }^{7}$, así como la existencia de indicios serios y racionales de criminalidad de suficiente entidad que recaigan sobre una persona en concreto (sospechosa o investigada) y que, consiguientemente, permitan individualizar la medida o diligencia - de investigación - a realizar (González-Cuéllar Serrano, 1990: 305-310; Iglesias Canle, 2003: 89-101; Iglesias Canle, 2006: 182-193). Todo ello obedece al propósito de que el resultado final al que llegue la causa se haya logrado a través del empleo de métodos válidos, quedando libre de trampas, de suerte que la «victoria» de cualquiera de los «bandos» (acusación/defensa) sea justa y objetiva.

Lo anterior debe ser puesto necesariamente en sintonía con lo preconizado en el segundo apartado del citado precepto constitucional, el cual determina que: «Asimismo, todos tienen derecho al Juez ordinario predeterminado por la ley, a la defensa y a la asistencia de letrado, a ser informados de la acusación formulada contra ellos, a un proceso público sin dilaciones indebidas y con todas las garantías, a utilizar los medios de prueba pertinentes para su defensa, a no declarar contra sí mismos, a no confesarse culpables y a la presunción de inocencia». Así pues, a lo largo de los distintos epígrafes que componen el presente trabajo iremos desgranando el significado y alcance de los extremos relativos al derecho de defensa y la asistencia letrada, las garantías procesales (donde ostenta un importante papel el principio de contradicción), los medios pertinentes para ejercitar la defensa y el debido respeto a la presunción de inocencia, si bien limitándonos a su proyección en el contexto de la realización y valoración de pruebas de $\mathrm{ADN}$ en el ámbito del proceso penal, así como de la inscripción de identificadores genéticos en la base de datos policial.

\section{EL MARCO NORMATIVO GENERAL EXISTENTE ANTES Y DESPUÉS DE LA REFORMA OPERADA POR LA LEY ORGÁNICA 13/2015, DE 5 DE OCTUBRE}

\section{PROBLEMÁTICA LIGADA A LA EXISTENCIA DE LAGUNAS Y PARQUEDAD NORMATIVA}

La ausencia de una regulación completa y específica en materia de intervenciones corporales (en general) y pruebas de ADN (en particular) en el ordenamiento jurídico español se ha convertido en una constante queja

$7 \quad$ Elemento que se categoriza como una cuestión de proporcionalidad estricta. 
por parte de la doctrina (Iglesias Canle, 2003: 126; Armengot Vilaplana: 2017: 18) $)^{8}$.

Las primeras menciones que se introdujeron en nuestra normativa procesal penal en lo que respecta a las pruebas de $\mathrm{ADN}$ vinieron de la mano de la Ley Orgánica 15/2003, de 25 de noviembre, por la que se modifica la Ley Orgánica 10/1995, de 23 de noviembre, del Código Penal de 2003, que mediante la letra b) del número 1 de su disposición final primera ańadió tanto el párrafo tercero al art. 326 como el párrafo segundo del art. 363, ambos de la LECrim.

Hasta entonces, en la práctica se ordenaban y efectuaban medidas de intervención corporal, pero sin la debida concurrencia del principio de legalidad, requisito constitucional, que se venía supliendo jurisprudencialmente con la emisión de una autorización judicial motivada y teniendo en cuenta que la normativa internacional y la doctrina del Tribunal Europeo de Derechos Humanos avalaban la práctica de dichas diligencias o actuaciones, siempre y cuando se cumpliesen las exigencias derivadas del principio de proporcionalidad, pero reclamando igualmente una previsión legal explícita y concreta que se cristalizó al fin, al menos en cierta medida, con la inclusión en la LECrim de los dos preceptos indicados (Pérez Marín, 2008: 29)9 .

Así, el art. 326.3 de la $\mathrm{LECrim}^{10}$ se refiere a la recogida de muestras biológicas dubitadas y aparentemente no plantea ninguna deficiencia, salvo que reparemos en la más que escasa forma en la que alude a la correcta observancia de la cadena de custodia. En efecto, no se define este elemento ni se matiza cómo se han de recoger, embalar, conservar, transportar, etc., las muestras para poder asegurar su autenticidad y, en última instancia, la precisión y

8 De hecho, en la actualidad, únicamente contamos con referencias legales expresas en lo que atañe a las pruebas de alcoholemia y a los análisis genéticos, si bien en este último caso, las mismas son susceptibles de ampliación y perfeccionamiento, por las lagunas que origina su parquedad, amén de por su falta de sistematicidad, como expondremos a continuación.

9 Véanse aquí como referentes las SSTC 37/1989, de 15 de febrero, y 207/1996, de 16 de diciembre. Incluso el Tribunal Supremo criticó el panorama de anomia legal e inseguridad jurídica reinante, entre otras, en la STS 803/2003, de 4 de junio.

10 El cual establece que «cuando se pusiera de manifiesto la existencia de huellas o vestigios cuyo análisis biológico pudiera contribuir al esclarecimiento del hecho investigado, el Juez de Instrucción adoptará u ordenará a la Policía Judicial o al médico forense que adopte las medidas necesarias para que la recogida, custodia y examen de aquellas muestras se verifique en condiciones que garanticen su autenticidad, sin perjuicio de lo establecido en el artículo 282». 
fiabilidad de los resultados de los análisis genéticos (Cabezudo Bajo, 2012: 9-11 y 21; Soleto Muñoz: 2009: 141) ${ }^{11}$.

Por su parte, el art. 363.2 de la LECrim resultó bastante más controvertido $^{12}$. En primer término porque el legislador pareció confundir las acepciones «inspección», «registro» e «intervención corporal» al diseñar su redacción. Ello por cuanto para llevar a cabo una diligencia de obtención de muestras biológicas indubitadas al objeto de extraer ulteriormente los perfiles $\mathrm{ADN}$, la medida que resulta necesario practicar no es otra que una intervención corporal y de carácter leve (esto es, básicamente, un frotis bucal o nasal, un frotis epitelial, una extracción capilar...), pero en ningún caso tiene sentido someter a la persona sospechosa/investigada a una inspección o registro o a otro tipo de medida de intervención corporal con esta finalidad ${ }^{13}$.

En segundo término, este precepto obvió dos cuestiones transcendentales. Por un lado, no arbitró solución alguna para los supuestos en que la persona sospechosa/investigada (anteriormente «imputada») se negase a

11 Tampoco tiene en cuenta este artículo el modo en el que en la praxis se procede a inspeccionar la escena delictiva (por parte de los distintos efectivos policiales y los/as facultativos/as forenses), pudiendo haber sido tales extremos previstos de forma más concisa y adaptada a la realidad forense.

12 En virtud del cual se dispone que «siempre que concurran acreditadas razones que lo justifiquen, el Juez de Instrucción podrá acordar, en resolución motivada, la obtención de muestras biológicas del sospechoso que resulten indispensables para la determinación de su perfil de ADN. A tal fin, podrá decidir la práctica de aquellos actos de inspección, reconocimiento o intervención corporal que resulten adecuados a los principios de proporcionalidad y razonabilidad». Dicho precepto debe ser puesto en correlación con la disposición adicional tercera de la Ley Orgánica 10/2007, de 8 de octubre, que determina que «la policía judicial procederá a la toma de muestras y fluidos del sospechoso, detenido o imputado, así como del lugar del delito. La toma de muestras que requieran inspecciones, reconocimientos o intervenciones corporales, sin consentimiento del afectado, requerirá en todo caso autorización judicial mediante auto motivado, de acuerdo con lo establecido en la Ley de Enjuiciamiento Criminal».

13 Cosa distinta es que por las circunstancias y tipo delito cometido resulte necesario obtener los perfiles genéticos de la víctima. Pensemos, por ejemplo, en el caso de una agresión sexual, para lo cual sí sería necesario, siempre con consentimiento expreso de la víctima y teniendo en cuenta las garantías que, en atención a la normativa europea aprobada previamente, exige con particularidad en su art. 21 de la Ley 4/2015 de 27 de abril, del Estatuto de la Víctima del Delito realizar una exploración corporal (que puede afectar a zonas especialmente íntimas o sensibles como la cavidad vaginal y/o anal). En cualquier caso, el art. 363 no hace referencia a esta eventualidad por cuanto se refiere únicamente al sospechoso. 
someterse a una diligencia de estas características. Tal coyuntura tuvo que ser nuevamente resuelta por la doctrina y la jurisprudencia, que trataron de discernir si nos encontrábamos ante una carga procesal o ante una obligación procesal.

El sector de la doctrina que abogaba por la primera opción estimaba que como «reprimenda» a la actitud renuente de la persona sospechosa/investigada habría que atribuir la aplicación de un indicio incriminatorio (Huertas Martín, 1999: 410-413). Por el contrario, aquellos/as autores/as que se decantaban por la segunda alternativa consideraban que la medida debía practicarse acudiendo a la coacción física (González-Cuéllar Serrano: 1990: 290-297), siempre de forma subsidiaria y con pleno respeto al principio de proporcionalidad, y ello porque tal opción resultaba a la postre más garantista, dada la ambivalencia por la que se caracterizan las pruebas de ADN y el hecho de que sus resultados, en caso de ser positivos, es decir, de coincidencia entre perfiles dubitados e indubitados, han de ser interpretados siempre de forma indiciaria y probabilística (Iglesias Canle, 2003: 149-159; Romeo Casabona y Romeo Malanda, 2010: 37-44). De facto, esta fue la postura que finalmente se acogió en el año 2015 en la LECrim. Sin embargo hasta ese momento, la jurisprudencia no pudo sino solventar tales situaciones con la atribución del indicio incriminatorio, habida cuenta de que resultaba palmariamente ilícito promover el recurso a medidas coercitivas sin una previsión legal concreta implementada a tal efecto, dada la afección de derechos fundamentales que ello implica $^{14}$.

Por otro lado, el art. 363.2 de la LECrim olvidó que además de la persona sospechosa/investigada también pueden ser objeto de pruebas de ADN terceras personas (como testigos, familiares o allegados de la víctima, etc.) e

14 En otra línea, se dictaron algunas resoluciones en las que se aplicó a modo de coerción indirecta la imputación de un delito de desobediencia o la advertencia de que podría llegar a imputarse el mismo, como una suerte de castigo. Véase aquí: ATC 405/2006, de 14 de noviembre; STS 803/2003, de 4 de junio, y SAP de Barcelona núm. 678/2004 (Sección 7.a), de 5 de julio. No obstante, esta opción fue pronto desechada, no solo porque no existía un tipo de desobediencia específico para tal situación a diferencia de lo que acontece en relación a las pruebas de alcoholemia (ex art. 383 del Código Penal), sino también por cuanto, a la postre, esta alternativa no servía sino para evitar la realización de pruebas de ADN, al dejar en manos de un/a posible culpable el buen éxito de la investigación y el proceso penal, teniendo en cuenta que este/a podría preferir enfrentarse a una pena por un delito de desobediencia y escapar a una pena por un delito más grave, como el de un homicidio (Abel Lluch, 2011: 139140; Gómez Amigo, 2003: 45). 
incluso la propia víctima y, por ello, no estableció el régimen jurídico aplicable a estos sujetos, con los problemas que ello suscita en la práctica ${ }^{15}$.

\section{LA CUESTIONABLE ACTUACIÓN DEL TRIBUNAL SUPREMO PARA JUSTIFICAR LA «VALIDEZ» DE LA OBTENCIÓN DE MUESTRAS BIOLÓGICAS «ATRIBUIDAS»O «ABANDONADAS»}

Como evidentemente la opción relativa a la atribución de un indicio incriminatorio no resultaba satisfactoria ni operativa, dado que al no facilitar la realización de pruebas de $\mathrm{ADN}$ no era una solución que ofreciese preponderancia a la verdad material, tras una polémica sentada ante la emisión de sentencias contradictorias por parte del Tribunal Supremo ${ }^{16}$, se dictó el acuerdo del Pleno de la Sala Segunda del Tribunal Supremo en la sesión celebrada el 31 de enero de 2006, según el cual «la Policía Judicial puede recoger restos genéticos o muestras biológicas abandonadas por el sospechoso sin necesidad de autorización judicial».

Empero, esta vertiente jurisprudencial, que fue acogida de similar manera en el ordenamiento jurídico italiano (Cisterna, 2014: 68-70), no puede calificarse

15 Pensemos sin ir más lejos en la práctica de determinadas pruebas de ADN realizadas sobre grupos de personas determinados, que se han llevado ya a cabo en nuestro país aun en ausencia de una regulación clara y detallada, en asuntos como el del asesinato de Eva Blanco o el asesinato del alcalde de Fago.

16 Nos hallábamos ante la existencia de dos líneas jurisprudenciales opuestas. Por una parte, la contenida en la STS 501/2005, de 19 de abril, que propugnaba que no se podían recoger y analizar muestras de $\mathrm{ADN}$ sin consentimiento del sospechoso, aunque estas estuvieran fuera de su cuerpo; y por otra parte la que sí avalaba la efectuación de dichas prácticas en tal sentido, contenida en la STS 1311/2005, de 14 de octubre. Finalmente, el citado acuerdo vino a dar cobertura a la segunda de las tesis, que fue de aplicación a partir de ese momento en ulteriores resoluciones, entre las que se pueden resaltar, SSTS 179/2006, de 14 de febrero; 701/2006, de 27 de junio; 1267/2006, de 20 de diciembre; 1190/2009, de 3 de diciembre; 685/2010, de 7 de julio; 827/2011, de 25 de octubre; 607/2012, de 9 de julio; 491/2013, de 31 de mayo; 767/2013, de 25 de septiembre, y 777/2013, de 7 de octubre. Estimaron también como prueba de cargo los resultados obtenidos de análisis genéticos practicados a partir de muestras «abandonadas» o «atribuidas», corroborando así la postura adoptada al respecto por el Tribunal Supremo, las SSTC 199/2013, de 7 de diciembre; 13/2014, de 30 de enero; 14/2014, de 30 de enero; 15/2014, de 30 de enero; 16/2014, de 30 de enero; 23/2014, de 13 de febrero y 43/2014, de 27 de marzo. Comentan esta particular cuestión autores como Figueroa Navarro (2015: 120-121) y Martín Pastor (2008: 87-103). 
en modo alguno de garantista, ni en lo que respecta a la autenticidad e incolumidad de las muestras biológicas así recabadas ni, por ende, a la fiabilidad de los resultados de los análisis practicados sobre las mismas, y mucho menos tomando en consideración las cuestionables y subrepticias tácticas en las que dicho acuerdo desembocó en la praxis. En este contexto, destaca como más preclaro ejemplo la hipótesis de los oficiales de policía que convidan a un vaso de agua a la persona sospechosa detenida, para que beba, o a un cigarrillo, para que fume, con el propósito de que cuando deje el vaso o la colilla «abandonados» en dependencias policiales, se pueda proceder — sin recabar su previo y necesario consentimiento consciente e informado y sin solicitar, en defecto del mismo, la oportuna autorización judicial—a analizar los restos de saliva que hayan quedado adheridos a tales objetos, lo que no es sino un subterfugio, a nuestro juicio constitutivo de un palmario engaño que escapa a las exigencias del principio de legalidad, amén del principio de proporcionalidad $y$, en consecuencia, vulnera el derecho a la tutela judicial efectiva y el derecho de defensa (Hernández García, 2010: 404; Moreno Verdejo, 2004: 1841; Silva Rodrigues, 2010: 545-551).

\section{LA NECESIDAD DE IMPLEMENTAR Y UTILIZAR, CON FINES DE INVESTIGACIÓN CRIMINAL, UNA BASE DE DATOS UNIFICADA COMPRENSIVA DE IDENTIFICADORES DE ADN Y LAS DEFICIENCIAS QUE ALBERGA LA LEY ORGÁNICA 10/2007, DE 8 DE OCTUBRE}

Otra manifiesta carencia que presentaba la regulación en materia de pruebas de ADN existente en España tenía que ver con la circunstancia de que en nuestro país no disponíamos de una base de datos de ADN unificada, motivo por el cual, ante los mandatos impuestos desde el ámbito europeo, nuestro legislador se vio abocado a aprobar, si bien con un más que reseñable retraso, la Ley Orgánica 10/2007, de 8 de octubre, reguladora de la base de datos policial sobre identificadores obtenidos a partir del $\mathrm{ADN}^{17}$.

En efecto, contar con un fichero de tales características es la única forma de poder asegurar la aplicación de lo que se denomina "coerción jurídica», que consiste básicamente en la inscripción de identificadores genéticos y datos

\footnotetext{
Tal y como se desprende de su art. 1, en ella se integran los ficheros de esta naturaleza de titularidad de las fuerzas y cuerpos de seguridad del estado tanto para la investigación y averiguación de delitos, como para los procedimientos de identificación de restos cadavéricos o de averiguación de personas desaparecidas.
} 
personales asociados a los mismos ${ }^{18}$ para la ulterior realización de cotejos a través de la base de datos, entre identificadores genéticos dubitados e identificadores genéticos inscritos en la base de datos con motivo de una causa anterior ${ }^{19}$. Se trata de un instrumento que permite el intercambio, fiable, ágil y seguro, resultando fundamental para el avance de las investigaciones penales tanto en el ámbito nacional como transnacional, razón por la cual su uso ha sido promovido por normas que persiguen potenciar la cooperación policial y judicial internacional y dotar de efectividad al Espacio Europeo de Libertad Seguridad y Justicia (De Hoyos Sancho, 2010: 152; Iglesias Canle, 2010: 1-9).

No obstante lo anterior, la citada norma alberga algunas deficiencias, que lejos de pasar desapercibidas, deberían ser objeto de una futura reforma que asuma - concienzudamente- como meta la preservación de los derechos fundamentales ${ }^{20}$. Así, sería recomendable que se especificase el régimen de conservación y destrucción de las muestras biológicas ${ }^{21}$ y se perfilasen/corrigiesen/completasen los periodos fijados en su art. 9 para proceder a la cancelación de identificadores genéticos, salvando ciertas fisuras, principalmente la eventualidad de que los datos de una persona sospechosa — que después no ha sido procesada- figuren inscritos más tiempo que los de una persona respecto de

18 El art. 3 de la Ley Orgánica 10/2007, de 8 de octubre, dispone que la inscripción de determinados identificadores obtenidos a partir del ADN no precisará consentimiento de la persona afectada y, más en concreto, «los datos identificativos extraídos a partir del ADN de muestras o fluidos que, en el marco de una investigación criminal, hubieran sido hallados u obtenidos a partir del análisis de las muestras biológicas del sospechoso, detenido o imputado, cuando se trate de delitos graves y, en todo caso, los que afecten a la vida, la libertad, la indemnidad o la libertad sexual, la integridad de las personas, el patrimonio siempre que fuesen realizados con fuerza en las cosas, o violencia o intimidación en las personas, así como en los casos de la delincuencia organizada, debiendo entenderse incluida, en todo caso, en el término delincuencia organizada la recogida en el artículo 282 bis, apartado 4 de la Ley de Enjuiciamiento Criminal en relación con los delitos enumerados».

19 Que pueden estar identificados o sin identificar, pero en este último caso, aunque no arrojen información sobre la identidad de la persona que se pretende localizar, sí posibilitan averiguar que un mismo sujeto ha tenido implicación con distintos hechos punibles.

20 Y, más en concreto, del derecho a la intimidad — genética-, del derecho a la autodeterminación informativa y del derecho a la presunción de inocencia.

21 Determinando el lugar, así como el personal habilitado a tal efecto y fijando periodos límite de tiempo, dado que el art. 5.1 en su inciso final únicamente contiene una parca referencia a esta cuestión al señalar que «corresponderá a la autoridad judicial pronunciarse sobre la ulterior conservación de dichas muestras o vestigios». 
la cual, tras toda la tramitación procesal oportuna, se dicta un auto de sobreseimiento libre o una sentencia absolutoria, estableciendo además un régimen específico para las inscripciones de identificadores genéticos pertenecientes a infractores que sean menores y también a víctimas (aunque estas últimas deben ser siempre voluntarias y revestir un carácter residual) ${ }^{22}$, ideas que entendemos se presentan acordes con lo preconizado en el art. 4 de la Directiva (UE) 2016/680 del Parlamento Europeo y del Consejo, de 27 de abril de 2016 ${ }^{23}$.

Asimismo, a nuestro parecer tendría que optarse por eliminar la posibilidad de inscribir directamente los perfiles genéticos pertenecientes a personas meramente sospechosas (en sede policial) a las que todavía no se les ha atribuido la comisión formal de un hecho punible y respecto de las cuales pueden archivarse las actuaciones ${ }^{24}$. En relación con este último punto, creemos que la opción que lograría el mayor equilibrio entre la promoción del buen éxito de las investigaciones penales ${ }^{25}$ y la salvaguarda de las garantías que deben asistir a las personas sospechosas/investigadas ${ }^{26}$ sería la de esperar a que estas alcancen, en su caso, el estatus de "encausadas" antes de proceder a la inserción de sus identificadores genéticos en la base de datos (Álvarez Buján, 2015: 113-114), los cuales deberán quedar condicionados a su eliminación tras el transcurso del periodo de tiempo que corresponda (ex art. 9 de la Ley Orgánica 10/2007, de 8 de octubre).

22 El tenor literal de dicho precepto es el siguiente: «La conservación de los identificadores obtenidos a partir del ADN en la base de datos objeto de esta Ley no superará: El tiempo seńalado en la ley para la prescripción del delito. El tiempo señalado en la ley para la cancelación de antecedentes penales, si se hubiese dictado sentencia condenatoria firme, o absolutoria por la concurrencia de causas eximentes por falta de imputabilidad o culpabilidad, salvo resolución judicial en contrario. En todo caso se procederá a su cancelación cuando se hubiese dictado auto de sobreseimiento libre o sentencia absolutoria por causas distintas de las mencionadas en el epígrafe anterior, una vez que sean firmes dichas resoluciones. En el caso de sospechosos no imputados, la cancelación de los identificadores inscritos se producirá transcurrido el tiempo señalado en la Ley para la prescripción del delito. En los supuestos en que en la base de datos existiesen diversas inscripciones de una misma persona, correspondientes a diversos delitos, los datos y patrones identificativos inscritos se mantendrán hasta que finalice el plazo de cancelación más amplio».

23 Que debe ser puesto en sintonía con su considerando n. 31.

24 Acerca de todos estos aspectos disertan, entre otros/as autores/as Caruso Fontán (2012: 164-165); De Hoyos Sancho, (2010: 178-181); Soleto Muñoz (2009: 161) y Soleto Muńoz (2016: 987-988 y 992), cuyos puntos de vista compartimos.

25 Además de la realización de la justicia y el ejercicio del ius puniendi.

26 Especialmente el principio de presunción de inocencia. 


\section{ASPECTOS ESENCIALES DE LAS REFORMAS LEGALES OPERADAS EN EL AÑO 2015}

Llegados a este punto, nos corresponde ahora hacer mención a las últimas reformas normativas aprobadas en el año 2015 en lo que atañe a la regulación de las pruebas de ADN y las bases de datos comprensivas de perfiles genéticos con fines de identificación e investigación criminal. Así, hemos de referirnos al nuevo art. 129 bis del Código Penal incorporado por el número setenta del artículo único de la Ley Orgánica 1/2015, de 30 de marzo, por la que se modifica la Ley Orgánica 10/1995, de 23 de noviembre, del Código Penal. Este fue el primer precepto que contempló la posibilidad de recurrir a la coacción física si así lo acuerda la autoridad judicial competente, pero refiriéndose a los supuestos en los que sea la persona condenada quien se niegue a someterse a la práctica de una prueba de ADN. Con esta previsión se trató de dar cumplimiento a lo dispuesto en el art. 37 del Convenio de Lanzarote, si bien se aumentó el elenco de delitos al hacer alusión a aquellos enunciados en el art. 3.1 a) de la Ley Orgánica 10/2007, de 8 de octubre, empleando de facto una redacción muy similar a la plasmada en este último precepto ${ }^{27}$. (Etxeberría Guridi, 2016: 623).

27 Dispone concretamente el art. 129 bis del Código Penal que: «Si se trata de condenados por la comisión de un delito grave contra la vida, la integridad de las personas, la libertad, la libertad o indemnidad sexual, de terrorismo, o cualquier otro delito grave que conlleve un riesgo grave para la vida, la salud o la integridad física de las personas, cuando de las circunstancias del hecho, antecedentes, valoración de su personalidad, o de otra información disponible pueda valorarse que existe un peligro relevante de reiteración delictiva, el juez o tribunal podrá acordar la toma de muestras biológicas de su persona y la realización de análisis para la obtención de identificadores de ADN e inscripción de los mismos en la base de datos policial. Únicamente podrán llevarse a cabo los análisis necesarios para obtener los identificadores que proporcionen, exclusivamente, información genética reveladora de la identidad de la persona y de su sexo. Si el afectado se opusiera a la recogida de las muestras, podrá imponerse su ejecución forzosa mediante el recurso a las medidas coactivas mínimas indispensables para su ejecución, que deberán ser en todo caso proporcionadas a las circunstancias del caso y respetuosas con su dignidad». El referido Convenio también motivó la aprobación del Real Decreto 1110/2015, de 11 de diciembre, por el que se regula el Registro Central de Delincuentes Sexuales, en el cual consideramos que no deberían incluirse perfiles genéticos, dado que esto representa una restricción del derecho a la intimidad — genética — y a la autodeterminación informativa innecesaria y, por tanto, poco proporcionada, por cuanto los mismos ya constarán insertados en la base de datos policial regulada por la Ley Orgánica 10/2007, de 8 de octubre, pudiendo ser consultados a través de dicho fichero. 
El art. 129 bis del Código Penal resultó en un primer momento novedoso porque cuando entró en vigor todavía no lo había hecho el art. 520.6 c), párrafo segundo, de la LECrim y, por consiguiente, aún no era —ni se sabía con plena seguridad si llegaría a serlo-, aplicable la coerción física en relación a personas investigadas. Una vez vigente este último precepto, el señalado art. 129 bis perdió en cierta medida su eficacia, peculiarmente, si tenemos en cuenta, por un lado, que la inscripción de identificadores genéticos de personas condenadas ya se contemplaba con anterioridad de forma implícita —a la vista del contenido del art. 9 de la Ley Orgánica 10/2007, de 8 de octubre (Etxeberría Guridi, 2016: 623-624) — ${ }^{28}$ y, por otro lado, que los supuestos en los que se llegue a dictar una sentencia condenatoria por la comisión de alguno/s de los ilícito/s comprendido/s en este artículo sin que se haya practicado la prueba de $\mathrm{ADN}$ - y la posterior inserción de identificadores genéticos en la base de datos policial - como una diligencia de investigación o, inclusive, de prueba, creemos que serán más bien residuales en la práctica.

Por su parte, el mencionado art. 520.6 de la LECrim cobró nueva redacción con la Ley Orgánica 13/2015, de 5 de octubre, de modificación de la Ley de Enjuiciamiento Criminal para el fortalecimiento de las garantías procesales y la regulación de las medidas de investigación tecnológica, destacando singularmente su apdo. c), párrafo segundo ${ }^{29}$.

Con tal previsión, y dada la imposibilidad palpable de alcanzar un acuerdo de índole político-legislativa que permita aprobar al fin un nuevo Código Procesal Penal que responda de una forma práctica a las necesidades actuales, incluyendo una regulación acabada en materia de intervenciones corporales y pruebas de $\mathrm{ADN}$, se logró proporcionar, a modo de parcheo, el respaldo legal necesario para acudir a la coerción física, bajo autorización judicial debidamente motivada de acuerdo con el principio de proporcionalidad. Sin embargo, su redacción no es del todo completa, por cuanto únicamente se

28 Pues si se obtienen los perfiles genéticos de una persona sospechosa/investigada y, tras toda la oportuna tramitación procesal, esta resulta condenada, la inscripción en la base de datos no será eliminada hasta que se produzca la cancelación de sus antecedentes penales.

29 Que determina que «si el detenido se opusiera a la recogida de las muestras mediante frotis bucal, conforme a las previsiones de la Ley Orgánica 10/2007, de 8 de octubre, reguladora de la base de datos policial sobre identificadores obtenidos a partir del ADN, el juez de instrucción, a instancia de la Policía Judicial o del Ministerio Fiscal, podrá imponer la ejecución forzosa de tal diligencia mediante el recurso a las medidas coactivas mínimas indispensables, que deberán ser proporcionadas a las circunstancias del caso y respetuosas con su dignidad». 
refiere al frotis bucal y no a ninguna otra medida equivalente y además alude exclusivamente, dado el lugar de la LECrim donde se ubica, al detenido y no a la persona investigada en general $^{30}$, si bien, haciendo una exégesis teleológica y sistemática, entendemos que la posibilidad de acordar una medida de tales características bajo los presupuestos marcados no puede limitarse únicamente a la persona detenida $-\mathrm{y}$ menos en fase policial—, sino que debe estimarse aplicable (en sentido amplio) a la persona investigada e incluso encausada. Además, no se concreta qué ha de entenderse por medidas coactivas mínimas indispensables, lo que, a fin de cuentas y hasta que se produzca una reforma $d e$ lege ferenda o la jurisprudencia matice su significado y alcance, parece ser un concepto jurídico indeterminado.

Con todo, el hecho de que la norma sea todavía reciente y que su tenor suscite dudas de interpretación en la judicatura no es excusa para eludir su aplicación y acudir a las soluciones empleadas hasta el momento, básicamente la utilización de muestras biológicas abandonadas o la atribución de un indicio incriminatorio en contra del sujeto investigado que se niegue a sujetarse a la efectuación de una prueba de ADN. Estas posibilidades únicamente se justificaban ante la ausencia de una previsión legal expresa que permitiese obtener - inclusive coactivamente- los perfiles genéticos de la persona investigada si esta no facilitaba su consentimiento a tal efecto. Una vez insertado en la LECrim un precepto que permite tal opción, la autoridad judicial debe dictar el pertinente auto motivado, especificando la medida a practicar y la forma en la que, de resultar necesario, ha de ser ejecutada coactivamente, así como el personal facultado para tales fines.

No obstante, que se haya introducido la citada previsión en nuestra LECrim, avalando el empleo de «medidas coactivas mínimas indispensables», no puede conducir a los órganos jurisdiccionales a convalidar actuaciones en relación a las cuales la prestación expresa y con plenas garantías del consentimiento no conste de forma nítida ${ }^{31}$, aduciendo que existe una suerte de consentimiento tácito, cuando no se ha opuesto una férrea resistencia física y uniendo esto al hecho de que el ordenamiento jurídico ampara ahora el recurso a las medidas coercitivas ${ }^{32}$, porque aunque es cierto que lo hace, ello

30 Como sí proponían, en cambio, en su momento, el Anteproyecto para un nuevo proceso penal de 2011 y el Borrador de Código Procesal Penal de 2013.

31 Por ejemplo, si no figura la firma en el acta de consentimiento informado que han de entregar las autoridades judiciales a la persona sospechosa/investigada y que ha de ser firmada por esta y su abogado/a.

32 Como parece considerarse, de forma cuestionable, en la STS 794/2015, de 3 de diciembre. 
se condiciona a la concurrencia de estrictos requisitos que se deben justificar en la pertinente y motivada autorización judicial.

\section{LA ASISTENCIA LETRADA INTEGRAL COMO GARANTÍA INEXCUSABLE}

Resulta llamativo que, encontrándonos ante una preclara restricción de derechos fundamentales ${ }^{33}$, se haya discutido candentemente durante un periodo de no pocos ańos, tanto por parte de la doctrina como de la jurisprudencia, que se ha pronunciado en diversas ocasiones de forma contradictoria, acerca de la preceptividad o no de la asistencia letrada para que una persona sospechosa/investigada preste su consentimiento a fin de someterse a una medida de toma de muestras biológicas indubitadas, necesaria para la realización de la subsiguiente prueba de ADN y la ulterior inscripción de sus identificadores genéticos en la base de datos policial.

Ciertamente, algunas resoluciones avalaron la práctica de este tipo de actuaciones considerando que no era preciso dispensar asistencia letrada a tal efecto, sobre la base de argumentos atinentes fundamentalmente a la escasa injerencia física de la medida (un frotis bucal) y a la ausencia de una previsión legal expresa que propugnase la obligatoriedad de tal requisito (Álvarez de Neyra Kappler, 2013: 8-9; Martínez Pardo, 2012: 51-54) $)^{34}$. Inclusive, el Anteproyecto de ley para un nuevo proceso penal de 2011, propuesta prelegislativa que no prosperó y cuyas premisas pueden entenderse superadas por el ulterior

33 Destacando con peculiaridad el derecho a la intimidad — genética— y el derecho a la autodeterminación informativa.

34 Véase, como resolución que avala la realización de una prueba de ADN sin haber concurrido asistencia letrada, la STS 634/2010, de 28 de junio. Autores como Gómez Colomer (2014: 41) tacharon incluso la exigencia de asistencia letrada como un requisito excesivamente garantista. Por su parte, Dolz Lago (2012: 6-7) vino a concluir, refiriéndose a un momento en el que todavía no era posible recurrir a la vis física en caso de negativa de la persona sospechosa/investigada a sujetarse a la práctica de una prueba genética, que proporcionar asistencia letrada podría suponer el incremento de las negativas sistemáticas a la realización de dicha diligencia, obstruyendo así el buen progreso del proceso penal. No obstante, no podemos suscribir en ningún caso esta idea porque desde el punto de vista de las garantías constitucionales y procesales - y del derecho de defensa - la asistencia letrada es imprescindible. Además, el problema que apuntaba este último autor no se resolvía eliminando tal presupuesto, sino diseñando una regulación completa, clara y sistematizada en materia de intervenciones corporales y prueba de ADN. 
Borrador de Código Procesal Penal de 2013, plasmaba en su art. 265.2 la idea de que si el imputado se hallase detenido podría prestar el consentimiento sin necesidad de asistencia letrada, siempre que no se utilizasen otros medios o instrumentos distintos del frotis bucal. No obstante, la línea jurisprudencial mayoritaria fue la de sostener la necesidad de asistencia letrada ciñéndola al supuesto de que la persona imputada se encontrase detenida ${ }^{35}$.

Con posterioridad, en el transcurso de diversos vaivenes doctrinales, jurisprudenciales y hasta prelegislativos ${ }^{36}$, se dictó el Acuerdo del Pleno No Jurisdiccional de la Sala Segunda del Tribunal Supremo de 24 de septiembre de 2014, que en su primer punto vino a reconocer la indispensabilidad de la asistencia letrada para la práctica de la diligencia de toma de muestras biológicas indubitadas y la posterior realización de la prueba de ADN con el consentimiento del imputado.

En efecto, esta línea ya había sido apuntada por cierto sector doctrinal, con el que convenimos plenamente, partiendo de la necesidad de que la persona sospechosa/investigada contase con un asesoramiento previo para otorgar su consentimiento — informado - al objeto de someterse a la práctica de una prueba de ADN (Pérez Marín, 2008: 190). Ello resulta imprescindible si tomamos en consideración la proyección que los resultados de los análisis genéticos pueden desplegar no solo en la causa penal concreta, toda vez que es posible que sirvan aquí para sostener la incriminación de la persona en cuestión, sino

35 Véase la STS 685/2010, de 7 de julio, cuya doctrina se reproduce en STS 827/2011, de 15 de octubre; 600/2013, de 10 de julio, y 140/2015, de 4 de marzo. Véanse también aquí, entre otras, las SSTS 767/2013, 25 de septiembre; 948/2013, de 10 de diciembre; 794/2015, de 3 de diciembre y 359/2017, de 19 de mayo. Esta tesis fue la adoptada también por el citado Borrador de Código Procesal Penal de 2013, que en su art. 284.3, al que remitía el art. 288.4, establecía la exigencia de asistencia letrada, pero limitando la misma a los casos en los que el sujeto pasivo de la medida se encontrase cautelarmente privado de libertad.

36 Incluso el Anteproyecto de Ley Orgánica de modificación de la Ley de Enjuiciamiento Criminal para la organización de la justicia penal, el fortalecimiento de las garantías procesales y la regulación de las medidas de investigación tecnológicas, de 5 de diciembre de 2014, contempló inicialmente — como una previsión más que desafortunada y contraria además a la doctrina puesta de manifiesto, pocos meses antes, en el Acuerdo del Pleno No Jurisdiccional de la Sala Segunda del TS de 24, de septiembre de 2014 - en la modificación que proponía para el contenido del art. 520 de la LECrim, relativo a los derechos del detenido, que «la asistencia letrada no será precisa para la recogida de muestras de sustancias biológicas del detenido con los fines previstos en la legislación sobre bases de datos policiales sobre identificadores obtenidos a partir de ADN». 
también por la futura utilización que potencialmente se puede dar a sus identificadores genéticos, visto que los mismos serán objeto de inscripción en la base de datos de ADN policial ex art. $3.1 \mathrm{a}$ ) y b), inciso segundo, de la Ley Orgánica 10/2007, de 8 de octubre, y, consiguientemente, podrán ser usados en la realización de comparaciones de perfiles genéticos llevados a cabo de forma automatizada a través de dicho fichero en otras futuras y distintas causas, afectando así, con todo ello, a su derecho a la autodeterminación informativa y, en no pocas ocasiones, inclusive, por extensión, a su derecho a la presunción de inocencia.

Amén de lo anterior, estimamos que el/la letrado/a debe estar presente en el momento de ejecución de la medida, con el propósito de controlar que se cumplan todas las garantías inherentes tanto en lo que concierne a la práctica de la misma, peculiarmente si se hace recurriendo al empleo de «medidas coactivas mínimas indispensables», ahora permitidas legalmente, como en lo atinente a la debida observancia de la cadena de custodia de las muestras biológicas extraídas (Iglesias Canle, 2003: 79).

Pero en contrapartida, el referido acuerdo del Tribunal Supremo, en su punto segundo, optó, como no podía ser de otra manera, dadas las consecuencias que ello supondría en la práctica ${ }^{37}$, por convalidar el contraste entre los identificadores obtenidos de muestras recabadas en la causa objeto de enjuiciamiento con los identificadores obrantes en la base de datos policial y procedentes de una causa distinta, aunque en la prestación del consentimiento no constase la asistencia de letrado/a, y ello, cuando la persona acusada no haya cuestionado la licitud y validez de tales datos durante la fase de instrucción ${ }^{38}$.

Ahora bien, todo el galimatías existente ha sido despejado, a nuestro parecer, de una forma diáfana. Como sabemos, el contenido esencial del

37 Pues de lo contrario, un importante número de los perfiles genéticos y datos personales asociados que se encuentran actualmente insertados en la base de datos de ADN policial tendrían que ser eliminados por considerarse ilícita su obtención y ulterior inscripción, con el perjuicio que ello provocaría desde la óptica de los recursos para la investigación criminal y, más en particular, de la funcionalidad de la base de datos, que necesita contar con perfiles de contraste.

38 Algunos autores, al igual que ciertos profesionales de la judicatura, consideran inadecuado estipular la fase de instrucción (aunque sea entendida en un sentido amplio, como ha determinado el Tribunal Supremo) como un plazo preclusivo para efectuar la impugnación de los resultados obtenidos. Véase, en relación con esta cuestión, el voto particular del magistrado Perfecto Andrés Ibáñez recogido en la STS 734/2014, de 11 de noviembre, y el voto particular del magistrado Antonio del Moral formulado en la STS 834/2016, de 3 de noviembre. 
derecho de defensa, al igual que el de sus derechos instrumentales, fue reformado primeramente a través de la Ley Orgánica 5/2015, de 27 de abril, y, algunos meses más tarde, por la Ley Orgánica 13/2005, de 5 de octubre, y ello con la finalidad de incorporar en el seno de nuestro ordenamiento jurídico las incuestionables exigencias que nos marca al respecto el legislador europeo, particularmente en las previsiones de la Directiva 2012/13/UE del Parlamento Europeo y del Consejo, de 22 de mayo, relativa al derecho de información en los procesos penales (que se transpuso al derecho interno con retraso, dado que el plazo a tal fin expiraba el 2 de junio de 2014) ${ }^{39}$.

Así las cosas, hubo de reconocerse como garantía la facultad de que toda persona a la que se le atribuya la comisión de un hecho punible ejercite su derecho de defensa desde el primer momento, ex art. 118.1 de la LECrim, pudiendo examinar las actuaciones con la debida antelación ${ }^{40}$, se estableció además expresamente - habida cuenta de los problemas que esta duda entrańaba en la práctica - la posibilidad de que el/la letrado/a pueda entrevistarse reservadamente con su defendido/a, incluso antes de que tenga lugar la primera declaración ante la policía, el Ministerio Fiscal o la autoridad judicial competente, ex arts. 118.2 y 520.6 d) del mismo cuerpo legal.

Allende y centrándonos en la efectuación de ciertas diligencias de investigación, entre las que puede entenderse comprendida la de obtención de muestras biológicas para la realización de la subsiguiente prueba genética, el art. 520.6 de la LECrim contempla como funciones del/de la letrado/a, en su apartado b), las de «intervenir en las diligencias de declaración del detenido, en las diligencias de reconocimiento de que sea objeto y en las de reconstrucción de los hechos en que participe el detenido». Asimismo, en su apartado c) comprende como una faceta de la asistencia letrada la tarea de «informar al detenido de las consecuencias de la prestación o denegación de consentimiento a la práctica de diligencias que se le soliciten ${ }^{41}$.

39 Y también en la Directiva 2010/64/UE del Parlamento y del Consejo, de 20 de octubre de 2010, relativa al derecho a interpretación y traducción en los procesos penales (cuyo plazo de transposición había finalizado el 27 de octubre de 2013).

40 Lo que se recoge explícitamente en el apartado b) de dicho precepto.

41 Como parangón de derecho comparado se presenta de interés el caso italiano, ya que la asistencia letrada aquí resulta exigible so pena de nulidad de la pericia genética, según lo previsto en la letra b del apdo. 2 del art. 224 bis del Codice di Procedura Penale, que establece la obligación de avisar a la persona afectada por la práctica de la medida de la facultad de hacerse asistir de un defensor o de persona de su confianza (Gabrielli, 2012: 116-121). Por su parte, en el seno del ordenamiento jurídico portugués, si bien no se dispone explícitamente en el art. 64 del Código de Processo Penal, 
En definitiva, queda patente, a la vista de la nueva regulación, que cuando una persona sospechosa/investigada es requerida — por las autoridades policiales - para que preste su consentimiento, debe contar a tal fin, en todo caso, con asistencia letrada, es decir, con independencia de cuál sea su situación procesal y de la medida en concreto que se vaya a practicar (un frotis bucal u otro tipo de intervención corporal leve, como una extracción capilar) ${ }^{42}$. Solamente de este modo se pueden salvaguardar las garantías preconizadas en el art. 24.2 de nuestro texto constitucional ${ }^{43}$. Y es más, es claro que la controversia existente al respecto, como ya hemos avanzado, queda ahora claramente dirimida, aunque la misma, en realidad, nunca debió haberse producido, pues si bien es cierto que la LECrim no era explícita respecto de la

que alude a los supuestos en que resulta obligatoria la asistencia letrada, el caso de la práctica de diligencias de toma de muestras biológicas indubitadas con fines de identificación genética, debe interpretarse que aquí la asistencia letrada es también preceptiva, puesto que en el art. 61.1 del Código de Processo Penal se establece que el arguido (equivalente en Espańa a la persona investigada, antes imputada) goza, en especial, en cualquier fase del proceso, salvo las excepciones establecidas en la ley, de determinados derechos y, concretamente, en el apartado e) recoge como tal el derecho de designar abogado o solicitar el nombramiento de un defensor (se colige que el precepto se refiere en este último inciso a la posibilidad de nombrar abogado/a de oficio). Asimismo, el art. $62.1 \mathrm{del}$ mismo cuerpo legal estipula que el arguido puede designar abogado en cualquier momento del proceso. Se invocan igualmente de aplicación a esta cuestión los arts. 64, 154.3 y 4, 171 y 172.3 de dicho texto normativo portugués.

42 Lo más habitual es que la medida a efectuar sea por excelencia el frotis bucal, dada la sencillez de su práctica, la escasa injerencia física que provoca y la peculiaridad de que el proceso para analizar la saliva es rápido y tiene un coste «asequible». De hecho, el art. 520.6 c, párrafo segundo, de la LECrim hace mención exclusivamente a esta medida, aspecto que no consideramos adecuado dado que, en función de las singularidades de la situación, pensando en la resistencia que de forma efectiva pueda oponer la persona en cuestión, a la hora de proceder a ejecutar la toma de la muestra biológica haciendo uso de la coacción física podría resultar más operativo y acorde con el principio de proporcionalidad el empleo de otro tipo de medidas, como una extracción capilar o un frotis epitelial.

43 Inclusive, en nuestra opinión, si tomamos en consideración de que potencialmente pueden existir sujetos pasivos de pruebas de ADN diferentes a la persona sospechosa/ investigada, pero que faciliten sus muestras biológicas voluntariamente, en el ámbito de una causa penal, con la finalidad de ser excluidas como sospechosas y coadyuvar al buen éxito de la investigación, sería más que aconsejable que tales personas contasen también con asesoramiento y asistencia letrada previa y que tal extremo se recogiese expresamente en una reforma de lege ferenda. 
cuestión objeto de examen en este epígrafe, a nuestro juicio la norma procesal penal debía haber sido interpretada de la mano de los axiomas constitucionales, adoptando, en consecuencia, la única solución acorde con el derecho de defensa y el derecho a la presunción de inocencia, sin obviar, por supuesto, las directrices pautadas desde la Unión Europea que, como desafortunadamente no es poco infrecuente, se introdujeron con notable demora en nuestro derecho interno ${ }^{44}$.

Ahora bien, como último aspecto a apuntar aquí, debe reseñarse que para poder ofrecer una asistencia letrada de carácter integral es necesario que tales profesionales posean conocimientos y formación específica no solo acerca del funcionamiento y utilidad no solo de las pruebas de ADN en el ámbito del proceso penal, sino también de la trascendencia de las inscripciones de identificadores genéticos en la base de datos policial, teniendo en cuenta, además, la tutela que debe dispensarse al derecho a la autodeterminación informativa y la facultad de ejercitar los derechos de acceso, rectificación y cancelación de que gozan, ex art. 9.3 de la Ley Orgánica 10/2007, de 8 de octubre, las personas afectadas por dichas inscripciones, esto es, sus defendidos $/ a s^{45}$.

\section{LA OTRA CARA DE LA MONEDA: PRUEBAS DE ADN PRACTICADAS A INSTANCIA DE LA DEFENSA}

Efectivamente, parece existir en el subconsciente generalizado — de la sociedad en general y, en ocasiones, de los propios operadores jurídicosla idea de que las pruebas de $\mathrm{ADN}$, amén de actuar como una especie de panacea (nada más lejos de la realidad, por los motivos que aduciremos en el siguiente epígrafe), conforman una herramienta al servicio únicamente de quien dirige la investigación penal y busca los medios para que pueda sostenerse una imputación formal y, posteriormente, una acusación ${ }^{46}$. Sin embargo,

44 A pesar de lo anterior, llama la atención que la STS 11/2017, de 19 de enero, al referirse a la necesidad de que el consentimiento informado para la realización de una diligencia de toma de muestras biológicas indubitadas se otorgue con asistencia letrada, se apoya en la STS 685/2010, de 7 de julio, olvidando el tenor general de las dos reformas efectuadas sobre la LECrim en el año 2015, y exigiendo tal requisito solamente en los supuestos en que el «imputado», ahora «investigado», se hallare detenido.

45 La Directiva (UE) 2016/680 del Parlamento Europeo y del Consejo, de 27 de abril de 2016, concede una vital importancia a estos derechos tanto en sus considerandos como en su articulado.

46 Juez/a de instrucción, Ministerio Fiscal y policía judicial. 
hemos visto que en el art. 24.2 de la CE se propugna el derecho de toda persona a emplear medios de prueba pertinentes para su defensa, a lo que debe sumarse la circunstancia de que el primer apartado del mismo precepto proscribe la indefensión, puesto que su concurrencia impide que se satisfaga la tutela judicial efectiva.

En este contexto, una de las normas pioneras en la materia que nos ocupa en el ámbito europeo y, más en concreto, la Recomendación n. ${ }^{\circ} 1$ (1992), del Comité de Ministros del Consejo de Europa a los Estados miembros, sobre la utilización del análisis de ácido desoxirribonucleico (ADN) dentro del marco de la administración de justicia penal, disponía en su principio 5 que «el recurso a la realización de análisis de $\mathrm{ADN}$ únicamente deberá estar permitido en todos los casos pertinentes, con independencia del grado de gravedad de la infracción».

A primera vista, tal afirmación podría presentarse extraña o más bien incongruente en lo que respecta al principio de proporcionalidad, toda vez que parece descartar la necesidad de que concurra el requisito de gravedad delictiva para acordar la efectuación de una prueba de ADN. No obstante, si dirigimos nuestra mirada, como apostilla con gran acierto Etxeberría Guridi (2014: 143), al memorándum explicativo que se adjunta a esta recomendación, podemos arribar al busilis de la cuestión, ya que la finalidad pretendida por el mencionado principio no es otra que la de "posibilitar a la defensa el recurso a los análisis de $\mathrm{ADN}$ en casos de menor gravedad, para así estar en posición de excluir la culpabilidad. Es por lo tanto desde la perspectiva del derecho a la defensa, esto es, el interés del sospechoso en demostrar su inocencia, o mejor dicho, en excluir desde el principio toda sospecha, desde donde se ha de entender la amplitud con la que la Recomendación admite el recurso a los análisis de $\mathrm{ADN}{ }^{47}$.

Consecuentemente, debe dejarse claro que en fase de instrucción también puede la defensa, haciendo gala de las garantías constitucionales y procesales que le asisten, solicitar como diligencia la realización de una prueba de ADN, si la misma resulta útil y pertinente, a fin de acreditar la ausencia de implicación en los ilícitos penales objeto de investigación por parte de su defendido/a. Ello a pesar de que rija el principio de presunción de inocencia

47 A modo de contraste, cabe valorar positivamente la previsión contenida en el ordenamiento jurídico portugués, particularmente, en el art. 8.1 de la Lei n. ${ }^{\circ}$ 5/2008, de 12 de fevereiro, donde se recoge explícitamente la posibilidad de que la toma de muestras biológicas indubitadas pueda ser efectuada a solicitud del arguido, esto es, lo equivalente a la persona investigada / encausada, en función de la fase procesal en la que nos situemos. 
porque, si bien sobre la base del mismo la carga de la prueba (de que una concreta persona ha realizado unos determinados hechos punibles) recae sobre la acusación, lo cierto es que a la defensa le pertenece el derecho de deducir pretensión exculpatoria y, en este sentido, puede diseñar una estrategia procesal arropada convenientemente por las oportunas diligencias de investigación y prueba.

En efecto, la gravedad delictiva no tiene que actuar como una cortapisa para el derecho de defensa, antes al contrario, ha de convertirse en un modo de velar por el mismo. Así, este presupuesto debe exigirse estrictamente, tal y como se infiere de la regulación prevista en nuestro ordenamiento jurídico, a la hora de autorizar judicialmente la práctica de una prueba de ADN cuando el sujeto en cuestión no otorga su consentimiento a tal fin. Igualmente, se trata este de un parámetro clave para decidir si procede aplicar «medidas coactivas mínimas indispensables» en caso de que resulte necesario ante la actitud renuente —oponiendo resistencia física- de la persona afectada. Por consiguiente, nos hallamos ante un criterio que tiene que converger cuando se adopta judicialmente o, en su caso, en dependencias policiales (si la persona afectada facilita su consentimiento previa y debidamente informado a tal efecto) una medida limitadora de derechos fundamentales en el marco del proceso penal, pero si la defensa, de forma voluntaria, como medio para acreditar su pretensión exculpatoria, desea hacerse valer de la práctica de una prueba de ADN, y la misma resulta necesaria, útil y pertinente, en nuestra opinión no puede atribuírsele a tal requisito carácter de obligatoriedad, de forma que si el ilícito penal no es de los catalogados como grave, la persona investigada/encausada vea cercenado su derecho a utilizar los medios de prueba pertinentes para su defensa ${ }^{48}$.

Ahora bien, tal argumento no se puede argüir de manera perversa, es decir, llevando a cabo una malinterpretación que termine por extender exagerada e

48 A nuestro juicio, en estos supuestos el gasto que supone la realización de los análisis de ADN no debe ser una razón para descartar dicha prueba cuando resulte útil y pertinente y pueda constituir una clave desde el punto de vista del ejercicio del derecho de defensa, debiendo ser su coste asumido con cargo al erario público, toda vez que en el fondo también se encuentra aquí en juego el interés público en la persecución de los delitos y la realización de la justicia, elementos para cuya consecución puede resultar de suma relevancia la efectuación de dicha prueba, que además reviste un carácter ambivalente. A lo anterior es necesario sumar la idea de que en el marco de un sistema judicial como el español, que responde a las garantías de un Estado de derecho, los motivos de índole económica no han de cercenar las posibilidades de defensa ni generar situaciones discriminatorias. 
injustificadamente y, al margen de la concurrencia de la gravedad delictiva, el ámbito de aplicación en el seno del cual se puede ordenar de oficio la práctica de medidas de toma de muestras biológicas indubitadas, los pertinentes análisis de laboratorio y la posterior inscripción en la base de datos de los perfiles de ADN obtenidos — ex art. 363.2, 520.6 c), párrafo segundo de la LECrim, y disposición adicional tercera de la Ley Orgánica 10/2007, de 8 de octubre-.

\section{LOS RESULTADOS DE UN ANÁLISIS DE ADN: LA SIMBIOSIS ENTRE LA CORRECTA VALORACIÓN PROBATORIA Y LA PRESERVACIÓN DEL DERECHO DE DEFENSA Y LA PRESUNCIÓN DE INOCENCIA}

Indicábamos ya con antelación que los resultados de los análisis genéticos deben ser interpretados en términos indiciarios y probabilísticos. Ello significa que la prueba de $\mathrm{ADN}$ en ningún caso posee un valor absoluto o pleno, salvo que sus resultados sean de exclusión, esto es, negativos, porque no exista coincidencia entre los perfiles genéticos cotejados (Iglesias Canle, 2003: 152154). Pero además, no se trata de una prueba directa sobre los hechos ni tampoco respecto de la autoría, sino indiciaria, porque lo único que demuestra es la presencia de una concreta persona en el lugar de comisión del delito o que esta ha mantenido contacto físico o sexual con la víctima (Armenteros León, 2007: 1882). Así pues, para poder acreditar la culpabilidad de la perpetración de un/os concreto/s hecho/s punible/s, tales circunstancias no serán suficientes, sino que habrán de ser puestas en relación con el resto pruebas e indicios (plurales, absolutamente acreditados y de naturaleza inequívocamente acusatoria $^{49}$ ) concurrentes en la causa (Álvarez De Neyra Kappler, 2013: 54-60; Iglesias Canle, 2003: 150-152).

La tecnicidad de esta prueba científica implica que de lege ferenda debería establecerse expresamente la necesidad de que los/as peritos/as que realicen los análisis y elaboren los informes aportados a la causa acudan al acto de juicio oral a ratificar el mismo y a someterse a las consideraciones y dudas que les trasladen las partes ${ }^{50}$. Además, habrán de explicar $-\mathrm{y}$ referir también en el informe pericial - los términos de la recogida de las muestras, el método técnico-científico empleado para efectuar el análisis en laboratorio y la fiabilidad

49 Véase, entre otras muchas, la STS 958/2011, de 22 de septiembre, que hace cita de las SSTC 174/85, 175/85, 160/88, 229/88, 111/90, 348/93, 62/94, 78/94, 244/94, 182/95, 24/1997 y 68/98. Véase también la STS 272/2015, de 12 de mayo.

50 En este sentido, partimos de la idea propuesta en su día por Iglesias Canle (2003: 149-150). 
del mismo, así como el significado de los resultados, interpretados sobre la base de los parámetros que marca el teorema de Bayes ${ }^{51}$, los cuales tendrían que ser conocidos por el órgano judicial, que es, en definitiva, el único competente para efectuar la valoración de la prueba y, en atención a la misma, llegar a la conclusión que proceda para dictar sentencia y argumentar la motivación de la misma.

En este orden de cosas, resulta de vital importancia la explicación que la persona acusada pueda dar acerca del motivo por el cual sus perfiles fueron hallados en el lugar de los hechos o en el cuerpo de la víctima y la verosimilitud de la misma (Iglesias Canle, 2003: 151-152). De hecho, consideramos que la defensa ha de elaborar una estrategia procesal que se base no en negar meramente los hechos, ni tampoco los resultados de la prueba de $\mathrm{ADN}^{52}$, sino en ofrecer y acreditar una hipótesis alternativa para explicar los mismos. En suma, a pesar de que rija el principio de presunción de inocencia y que la carga de probar recaiga en la parte acusadora, creemos que el conocimiento de los entresijos de las pruebas de ADN debe conducir a adoptar una posición activa en el proceso.

Dominar las particularidades de la prueba de ADN implica efectuar el debido seguimiento, a través de la documentación obrante en autos, de la cadena de custodia, a fin de detectar posibles contaminaciones o roturas en la misma que puedan ser aducidas por la defensa, en tiempo y forma oportunos, y no de una manera genérica, sino más bien justificada (lo que puede hacerse a través de la formulación de preguntas y solicitud de aclaraciones a los/as peritos/as que habiendo realizado el análisis y elaborado el informe acudan a deponer al acto del juicio oral), al objeto de sembrar como mínimo la duda

51 Que en síntesis, consiste en que el órgano juzgador multiplique su grado de creencia (expresado en forma de apuesta) acerca de la culpabilidad del sujeto en cuestión a priori (a la vista del resto de indicios y pruebas existentes) y lo multiplique por un factor que le ha de facilitar el perito la likelihood ratio, que se corresponde con la siguiente fórmula: la probabilidad del hallazgo científico dada la culpabilidad/la probabilidad del hallazgo dada la inocencia (Carracedo Álvarez, 1999: 304-306).

52 Y menos aún en tratar de proporcionar una interpretación artera de los mismos. Con certeza, la ignorancia sobre el funcionamiento y verdadera virtualidad de la prueba de ADN, así como la desidia existente por parte de los/as jueces/zas y tribunales para comprender tales aspectos, unido a la imprecisa o incorrecta forma en la que habitualmente los/as peritos/as exponen las conclusiones y resultados de sus informes, ha dado lugar a que los resultados de los análisis genéticos se hayan tratado de manipular según convenga a cada una de las partes, produciéndose lo que se conoce como la falacia de la acusación y de la defensa (Carracedo Álvarez, 1999: 303; Iglesias Canle, 2003: 154-156; Romeo Casabona y Romeo Malanda, 2010: 39-42). 
— fundada - acerca de la fiabilidad y validez de los resultados. Pues si tales extremos no quedan totalmente acreditados, la prueba de $\mathrm{ADN}$, en virtud del principio de presunción de inocencia, y en último término también del principio in dubio pro reo, no habrá de ser tomada en consideración ${ }^{53}$.

Solamente si se cumplen las pautas (de interpretación indiciaria y probabilística) que sucintamente hemos expuesto se podrá afirmar que la prueba de ADN ha sido adecuadamente apreciada en relación al caso en concreto, y esa correcta valoración es, a su vez, la única que, en última instancia, garantiza que se ha preservado el derecho de defensa y el derecho a la presunción de inocencia, de suerte que, tanto a la vista de todo el periplo procesal como de la motivación y fallo de la sentencia que finalmente se dicte, se pueda colegir que se ha satisfecho la tutela judicial efectiva que predica el art. 24 de la CE.

Es evidente que la consecución efectiva de las ideas aquí plasmadas únicamente se puede alcanzar si los diferentes operadores jurídicos cuentan con la formación específica suficiente acerca del funcionamiento y virtualidad de las pruebas de ADN y las inscripciones de identificadores genéticos, tema al que, enfocado desde una óptica eminentemente práctica, consideramos debería concederle prioridad el Consejo General de la Abogacía y el Consejo General del Poder Judicial a la hora de programar los cursos de formación anuales que, mediante el oportuno convenio marco de colaboración suscrito en su día, se comprometieron a impartir.

\section{CONCLUSIONES}

En atención a todo lo hasta aquí expuesto, y a modo de recapitulación, pero también de reflexión final, es claro que los análisis de ADN son una herramienta al servicio de la investigación delictiva y el buen éxito del proceso penal, pero no concebido solamente desde la posición de la parte acusadora. En efecto, estamos ante una prueba de carácter ambivalente y cuya realización puede ser solicitada también a instancia de la defensa, posibilidad que debe considerarse reconocida desde la Recomendación n. ${ }^{0}$ (1992), del Comité de Ministros del Consejo de Europa a los Estados miembros.

53 Véase en relación con esta cuestión lo acontecido en el caso del asesinato Meredith Kercher en Italia, donde dos de las tres personas, en un inicio, condenadas por la comisión de dicho crimen fueron finalmente absueltas ante las irregularidades que tuvieron lugar en la recogida y análisis de las muestras biológicas y que fueron puestas de manifiesto - y acreditadas - por sus respectivas defensas. Un estudio crítico y detallado sobre lo acontecido en este caso se encuentra en Igartua Salaverria (2016: 1-36). 
En cuanto a la regulación existente en materia de pruebas de ADN - e intervenciones corporales- en el ámbito de la investigación y el proceso penal en España y a pesar de la incorporación del nuevo art. 129 bis del Código Penal y de la modificación introducida en la redacción del art. 520.6 c), párrafo segundo de la LECrim, no cabe duda de que la misma debería ser ampliada y detallada e incluida de forma debidamente sistematizada dentro de un nuevo texto de Código Procesal Penal, supliendo las diversas lagunas que existen en la actualidad y que atañen básicamente, entre otros extremos, al régimen aplicable a los sujetos pasivos distintos de la persona investigada, a la cadena de custodia o a la interpretación y valoración probatoria de los resultados de los análisis genéticos.

Asimismo, sería recomendable que de lege ferenda se modificase la Ley Orgánica 10/2007, de 8 de octubre, en los términos apuntados con anterioridad y se adaptase igualmente, aprovechando la ocasión, a las últimas reformas habidas en 2015, sustituyendo la terminología de «imputado» por «investigado»/«encausado» y añadiendo la pertinente referencia a la obtención y eliminación de muestras biológicas y perfiles genéticos a personas condenadas ex art. 129 bis del Código Penal.

En efecto, tras el examen de los aspectos tratados en los distintos epígrafes de nuestro trabajo, se colige que a fin de salvaguardar plenamente el derecho a la tutela judicial efectiva y las garantías procesales básicas del art. 24.2 $\mathrm{CE}$, resulta indispensable contar con una regulación clara y completa, que cumpla estrictamente con las exigencias que dimanan del principio de legalidad, permita en la praxis la aplicación real y efectiva del principio de proporcionalidad y no dé lugar a problemas y malinterpretaciones fruto de lagunas, vacíos o inconcreciones normativas, que a la postre puedan llegar a comprometer ciertos derechos, como el derecho de defensa y el derecho a la presunción de inocencia.

Por otro lado, no cabe duda, especialmente al abrigo de la normativa vigente en la Unión Europea, además de las reformas que se han implementado con motivo de la misma en el seno de nuestra LECrim y, más en concreto, en los arts. 118 y 520.6 c) y d) de la LECrim, de la preceptividad de asistencia letrada para la realización de la diligencia de toma de muestras biológicas indubitadas ${ }^{54}$, y ello con la finalidad tanto de proporcionar el debido asesoramiento jurídico-procesal a la persona afectada por la medida, como de estar presente en la propia ejecución de la misma, a fin de comprobar que se

54 Independientemente de la situación procesal (detenida o no) en que se halle la persona sospechosa/investigada y de la medida de intervención corporal leve a practicar (frotis bucal u otra medida equivalente). 
cumplen las garantías y pautas necesarias. De hecho, la garantía de la asistencia letrada con carácter preceptivo puede $-\mathrm{y}$ opinamos que podía ya con anterioridad a las reformas efectuadas en el año 2015 sobre la LECrim-inferirse del significado del art. 24 de la CE. Y de hecho dicha preceptividad constituye, a nuestro juicio, la única forma de preservar el derecho de defensa de modo adecuado y, por tanto, la única opción realmente correcta desde una perspectiva constitucional.

Para asegurar con efectividad el cumplimiento del principio de presunción de inocencia, amén de otras garantías procesales, como la necesidad de que no se genere indefensión, dispensando una tutela judicial efectiva, resulta indefectible la correcta interpretación —indiciaria y probabilística- de los resultados que arrojen los análisis genéticos, partiendo de la base de que tales análisis en ningún caso acreditan por sí solos la culpabilidad. Así, como hemos señalado, la prueba de $\mathrm{ADN}$ ha de ser valorada siempre en conjunción con el resto de indicios y pruebas confluyentes en la causa en concreto, teniendo en cuenta que los identificadores/marcadores que se localizan y analizan deben ser siempre puestos en relación con un respectivo grupo poblacional (Carracedo Álvarez, 1999: 2006)55.

Con certeza, el hecho de que se trate una prueba científica no quiere decir que nos encontremos en modo alguno ante una prueba plena o absoluta que actúe como una suerte de elixir mágico que despeje toda duda de criminalidad ${ }^{56}$, sino meramente ante una prueba más dentro de todo el elenco de pruebas que se pueden practicar, que ha de ser valorada por la autoridad judicial competente al hilo de los parámetros apuntados ${ }^{57}$.

Tras todo lo expuesto, como última y somera consideración para cerrar el presente trabajo, solamente nos resta poner el acento en el desafío jurídico

55 Explica este autor, experto genetista de referencia internacional en el ámbito forense, que «dependiendo de la población que se tome como referencia [...] la probabilidad de inclusión o exclusión de un sospechoso con respecto a un delito determinado puede ser mayor o menor». Véase en lo atinente a esta cuestión el razonamiento contenido en la STS 607/2012, de 9 de julio.

56 Imagen que, muchas veces, lamentablemente, parece albergar la sociedad lega en general, como consecuencia de la falta de rigor y el amarillismo/sensacionalismo con los que en ocasiones retransmiten las noticias de contenido policial/judicial ciertos medios de comunicación, originando juicios paralelos.

57 Además, al contrario de lo que incluso con asiduidad se cree en la esfera jurídica, la prueba de $\mathrm{ADN}$ no ha de ser tomada como la principal por el órgano judicial, antes al contrario, debe ser aquella que se sirva como herramienta para corroborar o verificar el sentido/significado del resto de pruebas e indicios. 
que en el siglo xxi plantea la utilización —y regulación — de pruebas de ADN y bases de datos genéticos en el ámbito de la investigación criminal, y ello, desde una perspectiva claramente multidisciplinar, dada la vinculación de esta materia con diferentes disciplinas, destacando esencialmente el derecho constitucional, el derecho procesal, el derecho comunitario e incluso la filosofía del derecho.

\section{Bibliografía}

Abel Lluch, X. (2011). Cuerpo del delito e identificación formal del delincuente. Especial consideración de la toma de muestras. En X. Abel Lluch y M. Richard González (dirs.). Estudios sobre prueba penal. Actos de investigación y medios de prueba: inspección ocular, declaraciones de inculpados y testigos, intervenciones corporales y prueba pericial (vol. II.). Madrid: La Ley.

Álvarez Buján, M. V. (2015). Prueba de ADN, bases de datos genéticos y proceso penal: panorama normativo en Espańa y Portugal. Dereito, 24, 2, 85-118.

Álvarez de Neyra Kappler, S. (2013). El consentimiento informado en la toma de muestras genéticas a detenidos y la asistencia letrada. La Ley Penal: Revista de Derecho Penal, Procesal y Penitenciario, 102, 5-20.

Armengot Vilaplana, A. (2017). La obtención de muestras biológicas para la determinación del ADN. La situación legal y jurisprudencial tras las últimas reformas. La Ley Penal: Revista de Derecho Penal, Procesal y Penitenciario, 128, 1-32.

Armenteros León, M. (2007). Perspectiva actual del ADN como medio de investigación y de prueba en el proceso penal. Diario La Ley, 28 (6738), 1882-1895.

Bernal Pulido, C. (2007). El principio de proporcionalidad y los derechos fundamentales: el principio de proporcionalidad como criterio para determinar el contenido de los derechos fundamentales vinculante para el legislador. Madrid: Centro de Estudios Políticos y Constitucionales.

Cabezudo Bajo, M. J. (2012). La regulación del «uso forense de la tecnología del ADN» en España y en la UE: identificación de cinco nuevas cuestiones controvertidas. Revista General de Derecho Procesal, 26, 1-23.

Caruso Fontán, V. (2012). Base de datos policiales sobre identificadores obtenidos a partir del ADN y derecho a la intimidad genética. Foro, Nueva Época, 15 (1), 135-167. Disponible en: https://bit.ly/2S508P0.

Carracedo Álvarez, A. (1999). Valoración de la prueba del ADN. En M. B. Martínez Jarreta (dir.). La Prueba del ADN en medicina forense: la genética al servicio de la ley en el análisis de indicios criminales y en la investigación biológica de la paternidad (pp. 301-308). Barcelona: Masson.

Cisterna, A. (2014). L'esigenza di mantenere riservate le investigazioni giustifica i prelievi occulti senza modalità invasive. Guida al diritto, 37 (13), 67-70.

De Hoyos Sancho, M. (2010). Profundización en la cooperación transfronteriza en la Unión Europea: obtención, Registro e intercambio de perfiles de ADN de sospechosos. En C. 
Arangüena Fanego (dir.). Espacio Europeo de Libertad, Seguridad y Justicia: últimos avances en cooperación judicial penal (pp. 152-181). Valladolid: Lex Nova.

Dolz Lago, M. J. (2012). ADN y derechos fundamentales (breves notas sobre la problemática de la toma de muestras de ADN — frotis bucal—a detenidos e imputados). Diario La Ley, 7774, 1-22.

Etxeberría Guridi, J. F. (2014). La identificación de personas mediante pruebas genéticas y bancos de perfiles de ADN: evolución normativa en el contexto europeo. Revista de Derecho y Genoma, núm. extraordinario, 135-156.

- (2016). Cuestiones vinculadas a las intervenciones corporales y a las bases de datos de ADN en las recientes reformas del Código Penal y de la Ley de Enjuiciamiento Criminal. En M. Jimeno Bulnes y J. Pérez Gil (coords.). Nuevos horizontes del Derecho Procesal. Libro-Homenaje al profesor Ernesto Pedraz Penalva (pp. 607-627). Madrid: Bosch.

Figueroa Navarro, C. (2015). La cadena de custodia de las muestras biológica. En C. Figueroa Navarro (dir.). La cadena de custodia en el proceso penal (pp. 107-128). Madrid: Edisofer.

Gabrielli, C. (2012). Il prelievo coattivo di campioni biologici nel sistema penale. Torino: Giappichelli Editore.

Gómez Amigo, L. (2003). Las intervenciones corporales como diligencias de investigación penal. Navarra: Aranzadi.

Gómez Colomer, J. L. (2014). Los retos del proceso penal ante las nuevas pruebas que requieren tecnología avanzada: el análisis de ADN. En J. L. Gómez Colomer (coord.). La prueba de ADN en el proceso penal (pp. 23-67). Valencia: Tirant lo Blanch.

González-Cuéllar Serrano, N. (1990). Proporcionalidad y derechos fundamentales en el proceso penal. Madrid: Colex.

Hernández García, J. (2010). 99 cuestiones básicas sobre la prueba en el proceso penal. Madrid: Consejo General del Poder Judicial.

Huertas Martín, M. I. (1999). El sujeto pasivo del proceso penal como objeto de la prueba. Barcelona: Bosch.

Igartua Salaverria, J. (2016). Verosimilitud vs. prueba. (lecciones de una historia judicial italiana). Revista Iberoamericana de Argumentación, 13, 1-36.

Iglesias Canle, I. C. (2003). Investigación penal sobre el cuerpo humano y prueba científica. Madrid: Colex.

(2006). La nueva regulación de las medidas de intervención corporal en el art. 363.2 LECrim: la quiebra del principio de legalidad. En N. González-Cuéllar Serrano (dir.) y A. M. Sanz Hermida (coord.). Investigación y prueba en el proceso penal (pp. 175-202). Madrid: Colex.

- (2010). Análisis crítico de la Ley Orgánica 10/2007, de 8 de octubre, reguladora de la base de datos policial sobre identificadores obtenidos a partir de ADN. Revista General de Derecho Procesal, 20, 1-9.

Martín Pastor, J. (2008). Avances jurisprudenciales y legislativos sobre la prueba pericial de $\mathrm{ADN}$ en el proceso penal. En especial, la base de datos policial sobre identificadores obtenidos a partir del ADN, creada por la Ley Orgánica 10/2007, de 25 de noviembre. En C. Salcedo Beltrán (coord.). Investigación, genética y derecho (pp. 73-130). Valencia: Tirant lo Blanch. 
Martínez Pardo, V. J. (2012). La prueba del ADN en el proceso penal. Revista Jurídica de la Comunidad Valenciana: Jurisprudencia Seleccionada de la Comunidad Valenciana, 4, 39-58.

Moreno Verdejo, J. (2004). ADN y proceso penal: análisis de la reforma operada por la Ley orgánica 15/2003, de 25 de noviembre. Estudios jurídicos, 1801-1841.

Pérez Marín, M. A. (2008). Inspecciones, registros e intervenciones corporales. Las pruebas de ADN y otros métodos de investigación en el proceso penal. Valencia: Tirant lo Blanch.

Silva Rodrigues, B. (2010). Da prova penal. A Prova Cientifica: Exames, Análises ou Perícias de ADN? Controlo de Velocidade, Álcool e Substâncias Psicotrópicas (t. I). Lisboa: Rei dos Livros.

Romeo Casabona, C. M. y Romeo Malanda, S. (2010). Los identificadores del ADN en el Sistema de Justicia Penal. Cizur Menor: Aranzadi-Thomson-Reuters.

Soleto Muñoz, H. (2009). La identificación del imputado: rueda, fotos, ADN... De los métodos basados en la percepción a la prueba cientifica. Valencia: Tirant lo Blanch.

- (2016). Afectación de derechos en las fases de la prueba de ADN. En M. Jimeno Bulnes y J. Pérez Gil (coords.) Nuevos horizontes del Derecho Procesal. Libro-Homenaje al Prof. Ernesto Pedraz Penalva (pp. 977-996). Madrid: Bosch. 